\title{
KOMPOSISI DAN FLUKTUASI HASIL TANGKAPAN TUGUK DI SUNGAI LEMPUING, SUMATERA SELATAN
}

\author{
Dharmadi"1), Endi Setiadi Kartamihardja1), Agus Djoko Utomo²), dan Dian Oktaviani'1) \\ 1) Peneliti pada Pusat Riset Perikanan Tangkap, Ancol-Jakarta \\ 2) Peneliti pada Balai Riset Perikanan Perairan Umum, Mariana-Palembang \\ Teregistrasi I tanggal: 31 Maret 2008; Diterima setelah perbaikan tanggal: 7 Januari 2009; \\ Disetujui terbit tanggal: 18 Pebruari 2009
}

\begin{abstract}
ABSTRAK
Tujuan penelitian ini adalah untuk mengetahui komposisi dan fluktuasi hasil tangkapan tuguk pada periode berbeda yang dioperasikan di Sungai Lempuing, Sumatera Selatan. Kegiatan penelitian dilaksanakan dengan metode survei pada periode musim peralihan penghujan sampai dengan kemarau (bulan April), musim kemarau (bulan Juni) dan musim penghujan (bulan Desember) tahun 2007. Komposisi jenis ikan dan hasil tangkapan diperoleh berdasarkan pada data pengambilan contoh pada saat ke lapangan dan data harian hasil tangkapan tuguk yang dicatat oleh 3 orang enumerator. Data dianalisis secara deskriptif. Hasil penelitian menunjukkan bahwa hasil tangkapan tuguk berbeda menurut periode waktu. Hasil tangkapan terdiri atas 11 jenis ikan untuk musim peralihan dan kemarau masing-masing berkisar $400-450 \mathrm{~kg}$ per unit per hari (rata-rata $411,2 \pm 14,1$ $\mathrm{kg}$ per unit per hari) dan 250-300 kg per unit per hari (rata-rata 263,3 $\pm 13,4 \mathrm{~kg}$ per unit per hari) dan 13 jenis ikan pada musim penghujan (bulan Desember) berkisar 700-750 kg per unit per hari (rata-rata $724,8 \pm 17,7 \mathrm{~kg}$ per unit per hari). Hasil tangkapan didominansi oleh jenis ikan lele (Clarias melanoderma) dan baung (Mystus nemurus). Selama penelitian, kandungan oksigen terlarut di perairan relatif rendah, berkisar 2-4 mg per I, namun dapat ditolelir oleh kelompok jenis ikan rawa (black fish).
\end{abstract}

KATAKUNCI: hasil tangkapan, komposisi, tuguk, Sungai Lempuing, Sumatera Selatan

ABSTRACT: Catch composition of filtering device and its fluctuation in the Lempuing River, South Sumatera. By: Dharmadi, Endi Setiadi Kartamihardja, Agus Joko Utomo, and Dian Oktaviani

This research proposed to observed a catch composition and fluctuation of filtering device in different periods operated in the Lempuing River, South Sumatera. The research was conducted using survey method at a respective month of April (transition season), June (dry season) and December 07 (wet season). Fish composition and catch of tuguk were noted during survey and based on recording 3 enumerators. Descriptive analysis was used in this study. The results show that the catch of filtering device differed on diferent season periodes. A number of 11 fish species was caught at a respective season of transition season (April) of $400-450 \mathrm{~kg}$ per unit per day (average $=411.2 \pm 14,1 \mathrm{~kg}$ per unit per day), dry season (June) of 250-300 kg per unit per day (average $=263,3 \pm 13,4 \mathrm{~kg}$ per unit per day), whilst at rainy season (December), fish catch composed of 13 fish species, ranging $700-750 \mathrm{~kg}$ per unit per day or (average $=724.8 \pm 17.7 \mathrm{~kg}$ per unit per day). Clarias melanoderma and Mystus nemurus were dominantly caught in the Lempuing River waters. During observation, dissolved oxygen content was relatively low (2-4 mg per I), that but could be tolerated by black fish.

\section{KEYWORDS: $\quad$ catch, composition, filtering device, Lempuing River, South Sumatera}

\section{PENDAHULUAN}

Di Sumatera Selatan, izin penangkapan ikan, baik di sungai maupun anak sungai, diberikan melalui lelang lebak lebung sehingga hanya nelayan atau kelompok nelayan pemenang lelang yang berhak melakukan penangkapan ikan di perairan tersebut (Gaffar, 2006). Pengaturan hak pengelolaan dan penangkapan ikan di perairan lebak lebung dan sungai, khususnya di Kabupaten Ogan Komering Ilir, Sumatera Selatan diatur oleh Peraturan Daerah No.30 tahun 2002, yaitu melalui proses pelelangan yang dilakukan secara rutin setiap tahun. Salah satu perairan yang pengelolaan dan penangkapan ikan dilakukan melalui proses pelelangan adalah Sungai Lempuing. Sungai Lempuing merupakan salah satu contoh ekosistem sungai yang mewakili paparan banjiran (river floodplain) yang daerah banjiran terjadi selama musim penghujan (Nasution \& Sunarno, 2005). Perairan sepanjang Sungai Lempuing merupakan salah satu perairan umum yang menjadi sumber penghasil ikan bagi Kabupaten Ogan Komering Ilir, Sumatera Selatan, khususnya dan Propinsi Sumatera Selatan pada umumnya. Menurut 
Arifin (1978), salah satu ciri dari perairan lebak lebung yaitu memiliki fluktuasi air yang sangat berbeda antara musim penghujan dan kemarau. Pada musim penghujan air sungai meluap dan menggenangi daerah sekitar kecuali bagian tanah yang tinggi (talang). Pada musim kemarau air sungai menjadi surut sampai sebagian besar daerah sekitar kering, kecuali anakanak sungai serta tempat yang lebih dalam (Arifin \& Ondara, 1982; Samuel et al., 1990). Sesuai dengan kondisi habitat, cara dan alat tangkap yang digunakan untuk penangkapan ikan di perairan lebak lebung dibedakan atas penangkapan ikan di perairan sungai dan lebak.

Sungai Lempuing, selain sebagai sarana lalu lintas juga sebagai sentra penangkapan ikan yang diandalkan untuk mendapatkan penghasilan melalui aktivitas penangkapan ikan (Kartamihardja et al., 2008). Berbagai jenis alat tangkap dioperasikan di sepanjang Sungai Lempuing antara lain kilung, lulung, empang, corong, pancing, dan bubu salah satu jenis yang dioperasikan di sepanjang waktu yaitu alat tangkap tuguk. Tuguk adalah jenis alat tangkap perangkap yang banyak dijumpai di sepanjang perairan Sungai Lempuing, dan merupakan alat tangkap utama selain empang (Hoggarth \& Utomo, 1994). Dari hasil pengamatan terdapat 8 unit tuguk yang beroperasi di perairan tersebut. Sementara itu, kontribusi alat tangkap tuguk terhadap hasil tangkapan dari berbagai alat tangkap seperti kilung, corong, lulung, dan empang di Sungai Lempuing 33\% (Dinas Perikanan Kabupaten Ogan Komering Ilir, 2005).

Meskipun bersifat statis dan menghalangi migrasi ikan atau udang yang akan melakukan pemijahan (Utomo, 2001), tetapi alat tangkap tuguk di wilayah ini sampai sekarang menjadi tumpuan utama dalam mendukung kehidupan bagi nelayan di sekitar perairan Sungai Lempuing, karena operasional penangkapannya tidak mengenal musim. Sementara itu, Prasetyo et al. (1993) mengatakan bahwa aktivitas penangkapan dan hasil tangkapan ikan di perairan umum sangat tergantung pada musim. Intensitas penangkapan, jumlah, jenis alat tangkap yang digunakan, serta hasil tangkapan ikan dipengaruhi oleh kondisi ketinggian air di suatu perairan, hasil tangkapan semakin meningkat dengan berkurangnya ketinggian air (Nurdawati et al., 2005) dan hal ini berhubungan dengan musim penghujan dan kemarau. Selain itu, menurut Gaffar et al. (2005), usaha penangkapan ikan di perairan umum sangat dipengaruhi oleh stok ikan.

Tujuan penelitian ini adalah untuk mengetahui komposisi dan fluktuasi hasil tangkapan tuguk pada periode berbeda yang dioperasikan di perairan Sungai Lempuing, Sumatera Selatan.

\section{BAHAN DAN METODE}

Penelitian ini dilakukan di perairan Sungai Lempuing Kabupaten Ogan Komering Ilir, Sumatera Selatan pada periode berbeda, yaitu peralihan musim penghujan dan kemarau (bulan April), musim kemarau (bulan Juni), dan musim penghujan (bulan Desember) tahun 2007. Metode penelitian adalah dengan cara pengamatan langsung dan pengambilan contoh di lapangan serta wawancara dengan para pemenang lelang lebak lebung untuk mengetahui hasil tangkapan bulanan dari alat tangkap tuguk. Pada saat survei, jumlah contoh ikan hasil tangkapan alat tangkap tuguk yang diamati adalah 355 ekor. Sedangkan hasil tangkapan harian alat tangkap tuguk didapat dari 3 orang enumerator. Setiap enumerator mencatat 2-3 unit alat tangkap tuguk. Pengambilan contoh hasil tangkapan ikan tuguk dipilih secara acak pada 3 lokasi pemasangan tuguk di bagian hilir di Sungai Lempuing dengan jarak antar tuguk 500-1.000 m.

Bahan tuguk terdiri atas jaring nilon yang sudah dijalin dan waring yang dipasang pada bagian ujung. Ukuran mata jaring nilon mulai dari 0,5-2,0 inci dan ukuran mata waring $3 \mathrm{~mm}$. Bagian ujung tuguk diikat dan diberi pengapung sebagai tanda. Tuguk dihubungkan ke tonggak dari kayu balok yang dipancang berbentuk kuda-kuda berbaris sebagai penguat tuguk dan dihubungkan dengan kayu balok dari tiap-tiap pancang untuk mengikatkan tuguk. Tiang tuguk menggunakan bahan kayu nibung yang juga sebagai alat untuk mengatur naik turun tuguk dari permukaan air. Tuguk berukuran panjang $12,5 \mathrm{~m}$; lebar $5,0 \mathrm{~m}$; dan tinggi $5 \mathrm{~m}$, bagian mulut mempunyai lebar $5 \mathrm{~m}$ yang mengerucut ke bagian ujung hingga berdiameter 0,5 $\mathrm{m}$. Untuk mengetahui kandungan oksigen terlarut, dilakukan pengukuran di beberapa lokasi pengambilan contoh dengan menggunakan Water Quality Checker 24 TOA DK Hand-held Water Quality Meter. Lokasi pengambilan contoh (Gambar 1). Posisi stasiun pengambilan contoh diketahui dengan menggunakan alat Global Positioning System merk Garmin.

\section{HASIL DAN BAHASAN}

\section{Fluktuasi Hasil Tangkapan}

Fluktuasi hasil tangkapan pada periode musim berbeda dapat dilihat pada Gambar 2. Tabel 1 menunjukkan hasil tangkapan ikan berdasarkan pada badan air dan periode yang berbeda. Gambar 2 


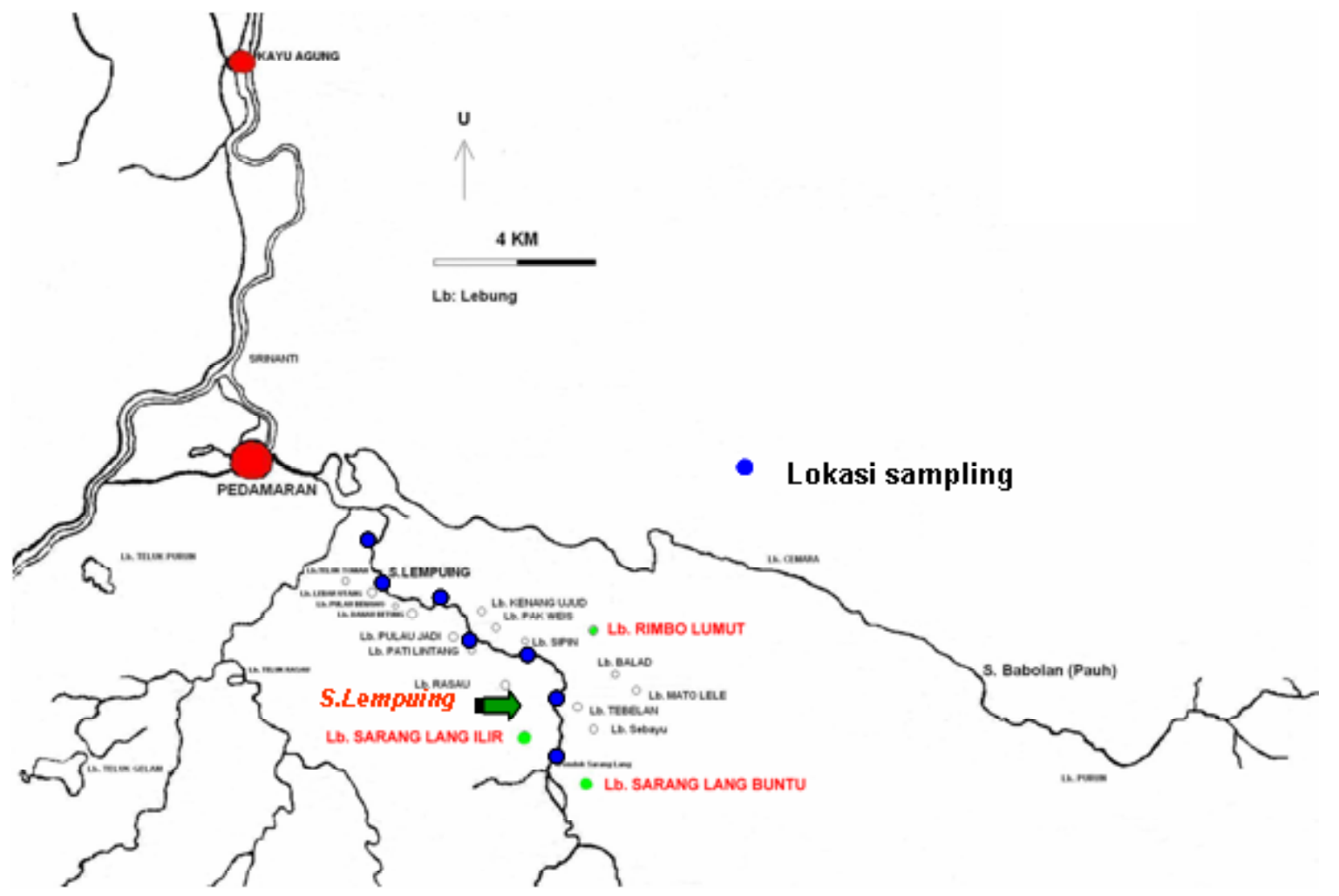

Gambar 1. Lokasi pengambilan contoh selama penelitian.

Figure $1 \quad$ Sampling site during research.

menunjukkan bahwa hasil tangkapan tuguk pada bulan Desember berkisar 700-750 kg per unit per hari atau rata-rata $724,807 \pm 17,677 \mathrm{~kg}$ per unit per hari lebih besar dibanding bulan April yang berkisar antara 400 450 per unit per hari atau rata-rata $411,197 \pm 14,142$ $\mathrm{kg}$ per unit per hari dan bulan Juni yang berkisar antara 250-300 kg per unit per hari atau rata-rata $263,321 \pm 13,435 \mathrm{~kg}$ per unit per hari. Jenis-jenis ikan yang tertangkap termasuk dalam kelompok ikan rawa (black fish) yang terdiri atas lele (Clariasmelanoderma), gabus (Channa striatus), lais (Cryptopterus spp.), sepat siam (Trichogaster pectoralis), baung (Mystus nemurus), tembakang (Helostoma temminckii), betok (Anabas testiduneus), toman (Channa micropeltes), dan rucah terdiri atas beberapa jenis ikan berukuran kecil dari famili Cyprinidae.

Besarnya hasil tangkapan ikan pada bulan Desember (saat musim penghujan) berkaitan dengan kelimpahan air yang mengalir di Sungai Lempuing. Kelimpahan air sungai disertai dengan arus deras dapat memberikan pengaruh positif terhadap kehidupan berbagai jenis ikan. Pada kondisi air sungai berlimpah aliran sungai akan membawa banyak nutrien yang berasal dari dasar sungai yang dapat dimanfaatkan oleh ikan sebagai makanan selain plankton.
Pada musim penghujan daerah lebak akan tergenang air sehingga komunitas ikan rawa dan ikan putihan akan berbaur terdistribusi di sungai dan paparan banjiran. Dengan demikian, kelimpahan ikan di sungai akan meningkat sehingga peluang tertangkap tinggi. Welcomme \& Hagborg dalam Hoggarth \& Utomo (1994) mengatakan bahwa hasil tangkapan ikan di perairan sungai pada musim banjiran lebih tinggi dibanding saat musim kering, meskipun pada saat musim kering keberadaan ikan lebih mudah tertangkap.

Tabel 1 menunjukkan bahwa perbedaan tipe badan air seperti rawa, sungai, anak sungai, dan sungai mati (oxbow lake) memberikan hasil tangkapan tuguk yang berbeda pada setiap unit dan lokasi pemasangan. Hasil tangkapan rata-rata dari alat tangkap tuguk yang dipasang di perairan sungai mati $112,5 \mathrm{~kg}$ per hari lebih tinggi dibanding hasil tangkapan tuguk yang dipasang di lokasi lain pada tipe badan air yang berbeda. Hal ini, terjadi karena daerah sungai mati berhubungan dengan daerah rawa sehingga kemungkinan besar sebagian kelompok ikan akan berenang menuju perairan tersebut untuk mencari makan atau berlindung dari ikan-ikan predator. Kemungkinan lain adalah mencari lokasi yang cocok untuk melakukan perkembangbiakan. 

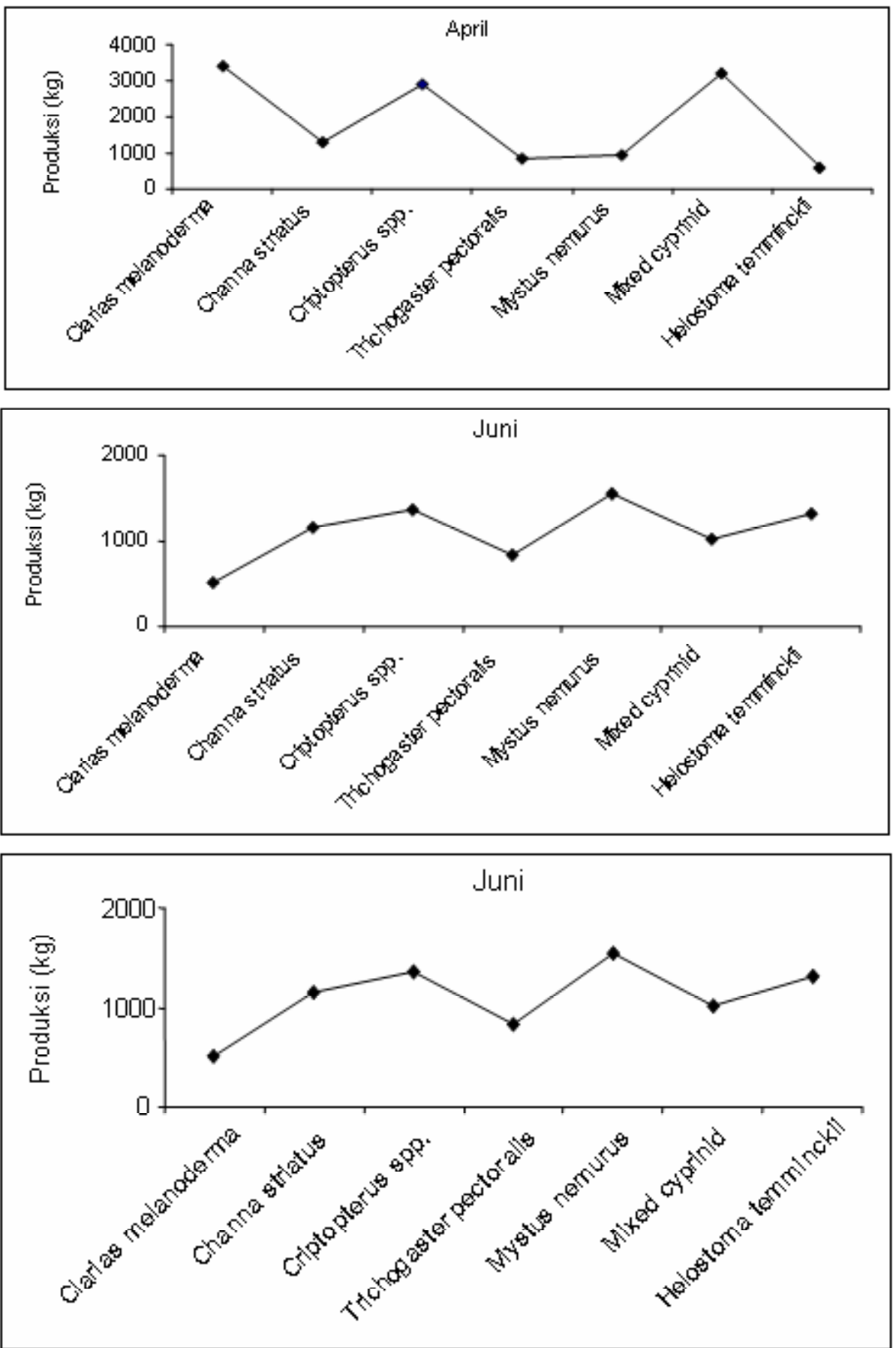

Gambar 2. Fluktuasi hasil tangkapan tuguk pada musim peralihan (bulan April), kemarau (bulan Juni), dan penghujan (bulan Desember) di Sungai Lempuing, Sumatera Selatan.

Figure 2. Catch fluctuation of filtering device on seasons of transition (April), dry (June), and rainy in the Lempuing River, South Sumatera.

\section{Komposisi Hasil Tangkapan}

Gambar 3 menunjukkan bahwa komposisi hasil tangkapan tuguk pada periode April dan Juni didominansi oleh jenis ikan yang berbeda di mana ikan lais, rucah (mixed cyprinid atau campuran beberapa jenis ikan berukuran kecil yang terdiri atas
Hampala macrolepidota, Labiobarbus ocellata, Barbodes gonionotus, Osetechillus hasselti, dan Barbodes schwanefeldi), dan lele, lebih besar dibanding dengan jenis ikan lain, yaitu berturut-turut 22,24 , dan $27 \%$. Sedangkan hasil tangkapan pada bulan Juni didominansi oleh ikan predator seperti ikan baung $(21 \%)$ dan jenis ikan lainnya (11-17\%). Hasil 
Tabel 1. Hasil tangkapan menurut alat tangkap ikan berdasarkan pada badan air dan musim di Sungai Lempuing

Table 1. $\quad$ Fish catch according to fishing gear based on water body and season in the Lempuing River, South Sumatera

\begin{tabular}{|c|c|c|c|c|}
\hline $\begin{array}{l}\text { Badan air/ } \\
\text { Water body }\end{array}$ & $\begin{array}{l}\text { Jenis alat tangkap/ } \\
\text { Fishing gears }\end{array}$ & $\begin{array}{c}\text { Kisaran hasil } \\
\text { tangkapan } \\
\text { (kg/hari)/Range of } \\
\text { fish catch (kg/day) }\end{array}$ & $\begin{array}{c}\text { Waktu } \\
\text { penangkapan/ } \\
\text { Fishing period }\end{array}$ & $\begin{array}{l}\text { Rata-rata hasil } \\
\text { tangkapan } \\
\text { (kg/hari)/ } \\
\text { Average catch } \\
\text { (kg/day) }\end{array}$ \\
\hline \multicolumn{5}{|l|}{ Rawa/Swamp } \\
\hline \multirow[t]{4}{*}{ - Lebak air hitam } & Kilung/Fyke nets & $5-100$ & Mei-Nopember & 55 \\
\hline & Tuguk/Stow nets & $10-50$ & Mei-Nopember & 30 \\
\hline & Empang/Trap & $3-10$ & Januari-April & 6,5 \\
\hline & Empang/Trap & $4-5$ & April-Juni & 4,5 \\
\hline \multicolumn{5}{|l|}{ Sungai/River } \\
\hline \multirow[t]{2}{*}{ - Laut Sekampung } & Tuguk/Stow nets & $2-10$ & Januari-April & 6 \\
\hline & & $50-100$ & Juli-Agustus & 75 \\
\hline \multirow[t]{2}{*}{ - Lubuk Lampam } & Tuguk/Stow nets & 4-5 & Januari-April & 4,5 \\
\hline & & $50-100$ & Juni-Agustus & 75 \\
\hline \multirow[t]{2}{*}{ - Sarang Elang Ilir } & Tuguk/Stow nets & $2-10$ & Januari-April & 6 \\
\hline & & $10-100$ & Juli-Agustus & 55 \\
\hline \multirow[t]{2}{*}{ - Sipin Ilir } & Tuguk/Stow nets & $3-5$ & Januari-April & 4 \\
\hline & Tuguk/Stow nets & $15-30$ & & 22,5 \\
\hline \multicolumn{5}{|l|}{ Anak Sungai/ } \\
\hline \multirow{5}{*}{$\begin{array}{l}\text { Branch river } \\
\text { - Sarang Elang Buntu }\end{array}$} & Lulung/Stationary & $25-400$ & Juni-September & 212,5 \\
\hline & uncovered pound nets & $10-50$ & Mei-Oktober & 30 \\
\hline & Kilung/Fyke nets & $10-100$ & Mei-Oktober & 55 \\
\hline & Kilung/Fyke nets & $2-3$ & Januari-Mei & 2,5 \\
\hline & Kilung/Fyke nets & $150-200$ & Juni-Nopember & 175 \\
\hline \multicolumn{5}{|l|}{$\begin{array}{l}\text { Sungai mati/ } \\
\text { Oxbow lake }\end{array}$} \\
\hline \multirow[t]{3}{*}{$\begin{array}{l}\text { - Lubuk Kemudi } \\
\text { - Danau Tiga }\end{array}$} & $\begin{array}{l}\text { Lulung/Stationary } \\
\text { uncovered pound nets }\end{array}$ & $15-500$ & $\begin{array}{l}\text { Mei-Nopember } \\
\text { Juni-Oktober }\end{array}$ & 257,5 \\
\hline & Kilung/Fyke nets & $100-150$ & & 125 \\
\hline & Tuguk/Stow nets & $75-150$ & Mei-Juli & 112,5 \\
\hline
\end{tabular}

tangkapan ikan pada ke dua periode tersebut memiliki jenis tangkapan ikan yang sama, yaitu terdiri atas 11 jenis ikan. Hasil tangkapan tuguk pada periode bulan Desember (musim penghujan) menunjukkan perolehan jenis tangkapan ikan yang lebih beragam (terdiri atas 13 jenis) dibanding dengan ke dua periode (April dan Juni). Keragaman jenis dan kelimpahan memiliki hubungan dengan mikrohabitat dan kandungan unsur hara perairan. Kondisi perairan pada saat musim penghujan juga akan memberikan kesempatan bagi ikan-ikan yang sudah matang kelamin untuk melakukan pemijahan dan perkembangbiakan. Selain itu, menurut Kartamihardja (2007), stok ikan di suatu perairan akan pulih dari eksploitasi pada waktu air tinggi (musim penghujan) di mana efisiensi penangkapan rendah, karena ikan terdistribusi ke kawasan yang tergenang.

Pada bulan Desember yang merupakan musim penghujan, hasil tangkapan tuguk lebih beragam jenisnya dibanding saat musim kemarau atau peralihan penghujan dan kemarau. Sedangkan pada waktu air rendah, ikan lebih terkonsentrasi dan cenderung melakukan ruaya aktif pada waktu air naik dan air turun. Pada kondisi ini, ikan lebih mudah tertangkap. Dengan demikian, struktur dan komposisi serta kelimpahan stok ikan direfleksikan dalam tipe dan intensitas penangkapan ikan pada waktu tersebut (Kartamihardja, 2007). Variasi musiman luapan air banjir pada musim hujan di sungai, selain mempengaruhi musim dan intensitas kegiatan penangkapan ikan, juga mempengaruhi karakteristik fisika kimia dan biologi perairan, baik di sungai utama dan anak-anak sungai maupun di habitat rawa banjiran (Welcomme, 1979). Beberapa jenis ikan putihan (white fish) tidak dapat hidup terus di lebung karena kualitas air yang memburuk sehingga ikan-ikan tersebut akan bergerak ke sungai utama. Jenis ikan rawa (black fish) dapat beradaptasi dalam kondisi kualitas air buruk dengan kandungan oksigen rendah 

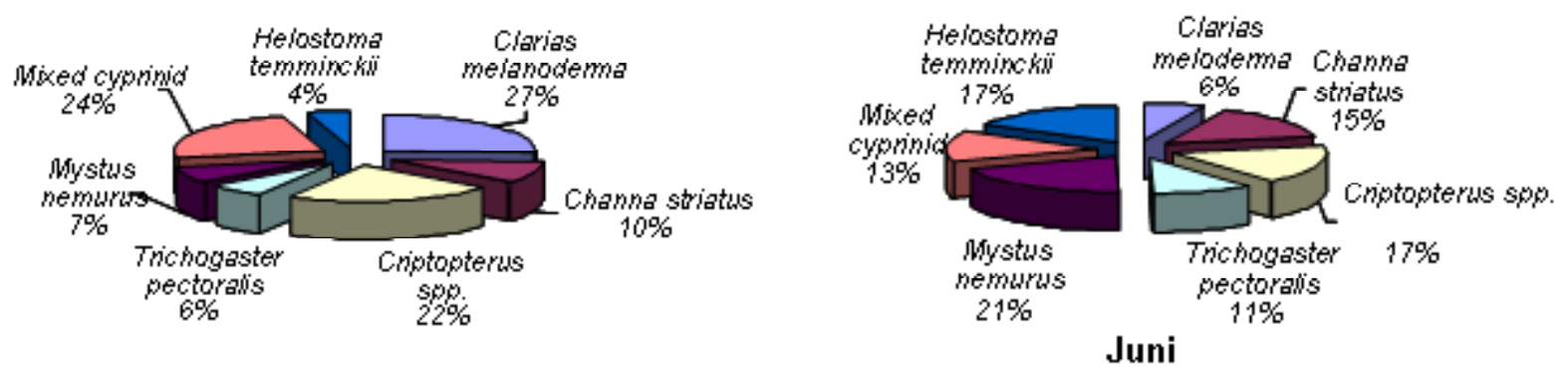

April

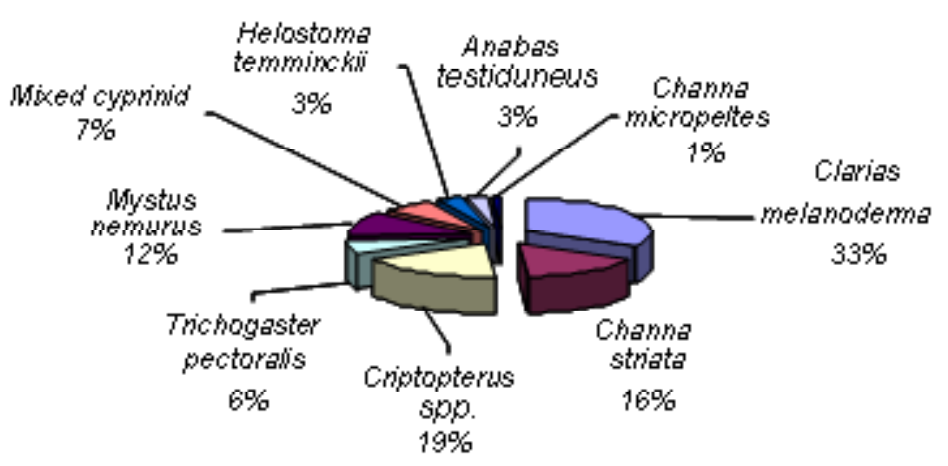

Gambar 3. Komposisi hasil tangkapan tuguk padabulan April, Juni, dan Desember di Sungai Lempuing, Sumatera Selatan.

Figure 3. Catch composition of filtering device on April, June, and December in the Lempuing River, South Sumatera.

karena jenis-jenis tersebut mampu mengambil oksigen secara langsung dari udara (Kartamihardja et al., 2008).

Kandungan oksigen di perairan Sungai Lempuing selama pengamatan berkisar 2-4 mg per I. Nilai tersebut relatif rendah meskipun dalam kondisi air mengalir. Air yang berwarna kecoklatan diduga akibat hasil dekomposisi bahan-bahan serasah atau pembusukkan dari akar dan daun yang berasal dari rawa-rawa atau lebak lebung, mengakibatkan menurunnya kandungan oksigen terlarut. Oleh karena itu, jenis-jenis ikan yang bertahan hidup di sungai pada kondisi rendah adalah jenis-jenis ikan labirin (dapat mengambil oksigen langsung dari udara). Welcomme (1979), mengatakan bahwa ikan putih (white fish) adalah ikan sungai yang membutuhkan kadar oksigen tinggi, sedangkan ikan hitam (black fish) merupakan ikan rawa yang tahan terhadap kadar oksigen rendah. Berdasarkan pada hasil pengambilan contoh, sebagian besar ikan yang tertangkap tuguk adalah jenis-jenis ikan yang bersifat labirintichi.

Menurut Prasetyo et al. (1992), alat tangkap tuguk merupakan jenis alat yang tidak selektif, karena teknik pemasangannya yang memotong sungai akan mengganggu migrasi ikan. Jumlah tuguk yang dioperasikan di sepanjang Sungai Lempuing relatif sedikit atau sekitar $7 \%$, dari jumlah alat tangkap lainnya, tetapi, dapat memberikan hasil tangkapan maksimal. Namun, jika ditinjau dari aspek biologi reproduksi, jenis alat tangkap ini berdampak negatif terhadap kelestarian sumber daya ikan, karena dapat menghalangi alur ruaya ikan atau udang untuk bereproduksi. Pada saat musim hujan, beberapa jenis ikan akan melakukan migrasi dari hilir ke hulu sungai, antara lain ikan patin (Pangasius pangasius), jelawat (Leptobarbus hoeveni), semah (Labeobarbus douronensis), dan udang (Macrobrahium sp.) (Utomo et al., 1992) dan alat tangkap tuguk sangat efektif menangkap ikan-ikan yang bermigrasi pada periode musim tersebut (Hoggart \& Utomo, 1994). Meskipun jumlahnya relatif sedikit alat tangkap tuguk dapat memberikan dampak negatif yang signifikan bagi keberlangsungan hidup suatu populasi ikan dan udang di perairan tersebut. Menurut Utomo (2001), tuguk merupakan jenis alat tangkap statis yang bersifat membahayakan kelestarian sumber daya ikan karena cara operasional alat tangkap ini dengan memotong ruaya ikan atau udang yang akan melakukan pemijahan. Oleh karena itu, demi menjaga kelestarian sumber daya perikanan khususnya di perairan Sungai Lempuing, maka perlu dipertimbangkan penggunaan alat tangkap lain yang ramah lingkungan dan menjaga kelestarian sumber daya ikan. Kartamihardja (2007) mengatakan bahwa dalam upaya melestarikan 
sumber daya perikanan, maka pemerintah dalam hal ini Pemerintah Daerah, Dinas Perikanan, Lembaga Penelitian perlu bekerjasama dengan masyarakat nelayan maupun Lembaga Swadaya Masyarakat.

\section{KESIMPULAN}

Berbagai jenis ikan sungai tertangkap dengan tuguk dan hasil tangkapannya pada periode berbeda didominansi oleh ikan lele dan baung. Perbedaan musim berpengaruh terhadap komposisi dan hasil tangkapan tuguk. Bulan Desember merupakan waktu yang paling baik untuk melakukan penangkapan ikan di Sungai Lempuing dibanding April dan Juni. Namun demikian, dampak negatif dari pemasangan alat tangkap tuguk di sungai adalah terhalangnya ikanikan yang bermigrasi untuk melakukan reproduksi.

\section{PERSANTUNAN}

Kegiatan dari hasil riset ekologi dan pengelolaan perikanan di perairan Lebak Lebung, Sumatera Selatan, T. A. 2007, di Pusat Riset Perikanan Tangkap, Ancol-Jakarta.

\section{DAFTAR PUSTAKA}

Arifin, Z. \& Ondara. 1982. Pengelolaan perikanan di perairan umum lubuk lampam. Prosiding Pusat Penelitian dan Pengembangan Perikanan No:9/ SPPU/1986. Badan Penelitian dan Pengembangan Pertanian.

Arifin, Z. 1978. Beberapa aspek tentang penangkapan ikan di perairan lubuk lampam. Simposium Modernisasi Perikanan Rakyat. LPPD Palembang. Jakarta. 27-30 Juni 1978. 19 pp.

Gaffar, A. K., M. Makmur, \& S. Nurdawati. 2005. Pemanfaatan sumber daya perairan umum bagi perikanan. Prosiding Forum Perairan Umum-I: Makalah Penunjang. Pusat Riset Perikanan Tangkap. Badan Riset Kelautan dan Perikanan. p.231-236.

Gaffar, A. K. 2006. Pengelolaan rawa untuk perikanan. Prosiding Seminar Nasional Forum Perairan Umum Indonesia III. Palembang, 27-28 Nopember 2006. Pusat Riset Perikanan Tangkap. Badan Riset Kelautan dan Perikanan. ISBN: 978-9791156-04-2. p. 241-247.

Hoggarth, D. D. \& A. D. Utomo. 1994. The fisheries ecology of the lubuk lampam river floodplain in south Sumatera, Indonesia. ELSEVIER. Fisheries Research. 20. 1994. p. 191-213.
Kartamihardja, E. S. 2007. Kebijakan pemacuan sumber daya ikan di perairan umum daratan Indonesia: Teknologi alternatif untuk meningkatkan produksi ikan dan pendapatan nelayan. Pusat Riset Perikanan Tangkap. Badan Riset Kelautan dan Perikanan. Seri Makalah Kebijakan Perikanan Tangkap: PP005/VII/2007. 18 pp.

Kartamihardja, E. S., Dharmadi, D. Oktaviani, Z. Fahmi, R. Puspasari, \& S. Nurdawati. 2008. Ekologi dan pengelolaan perikanan di perairan lebak lebung Sumatera Selatan. Laporan Tahunan/ Akhir. Pusat Riset Perikanan Tangkap. Badan Riset Kelautan dan Perikanan.

Nasution, Z. \& M. T. D. Sunarno. 2005. Pengelolaan perairan umum sungai dan rawa banjiran secara terpadu dan berkelanjutan. Prosiding Perairan Umum Indonesia I. Pusat Riset Perikanan Tangkap. Badan Riset Kelautan dan Perikanan. Departemen Kelautan dan Perikanan. ISBN:97997194-6-1. p. 437-447.

Nurdawati, S., Husnah, \& E. Dharyati. 2005. Pemanfaatan sumber daya perairan umum bagi perikanan. Prosiding Forum Perairan Umum I: Makalah Penunjang. Pusat Riset Perikanan Tangkap. Badan Riset Kelautan dan Perikanan. p. 207-216. ISBN: 979-97194-6-1.

Prasetyo, D., A. D. Utomo, Z. Nasution, \& A. S. Sarnita 1992. Aktivitas penangkapan ikan dan permasalahannya di perairan umum. Prosiding Temu Karya IImiah Perikanan Perairan Umum. Pengkajian Potensi dan Prospek Pengembangan Perairan Umum Sumatera Bagian Selatan. Palembang 12-13 Pebruari 1992. Badan Penelitian dan Pengembangan Pertanian. Pusat Penelitian dan Pengembangan Perikanan. Departemen Pertanian. Prosiding Pusat Penelitian dan Pengembangan Perikanan/No.26/1992. ISBN: 979-8186-28-1.

Prasetyo, D., A. D. Utomo, Z. Nasution, \& A. S. Sarnita. 1993. Aktivitas penangkapan ikan dan permasalahannya di perairan umum. Prosiding Temu Karya IImiah Perikanan Perairan Umum. Pengkajian Potensi dan Prospek Pengembangan Perairan Umum Sumatera Bagian Selatan. Pusat Penelitian dan Pengembangan Perikanan. Jakarta.

Samuel, Asyari, \& A. D. Utomo. 1990. Produktivitas perairan lubuk lampam daerah aliran Sungai Komering Sumatera Selatan. Buletin Penelitian Darat. 9 (1): 78-87. 
Welcomme, R. L. 1979. Fishes Ecology of Floodplain Rivers. Longman. London and New York. 319 pp.

Utomo A. D., Nasution Z, \& Adjie S. 1992. Kondisi ekologi dan potensi sumber daya perikanan sungai dan rawa. Makalah ilmiah Temu Karya Ilmiah Pengkajian Potensi dan Prospek Pengembangan Perikanan Perairan Umum Sumatera Bagian Selatan. Palembang. 12-13 Pebruari. 16 pp.
Utomo, A. D. 2001. Ruaya udang galah (Macrobrachium rosenbergii) di Sungai Lempuing, Sumatera Selatan. Institut Pertanian Bogor. Bogor. Tesis Pasca Sarjana. Program Studi IImu Perairan. $72 \mathrm{pp}$. 